\title{
Comparative study of soil test methods for determination of plant available potassium in Bulgarian arable soils
}

\author{
Lyudmila Angelova', Nezabravka Genova', Stiliyana Stoyanova', \\ Olya Surleva', Ioan-Hristian Nekov', Darya llieva', "Andriana Surleva ${ }^{1,2}$ \\ ${ }^{1}$ Analytical Chemistry dep, University of Chemical Technology and Metallurgy, \\ 8 St. Kl. Ohridski Blvd., 1756 Sofia, Bulgaria \\ ${ }^{2}$ Sembodja Ltd., 86 Osogovo str., Sofia, Bulgaria
}

Corresponding author: Andriana Surleva: e-mail: surleva@uctm.edu

Submitted 23 March 2021, received in revised form 31 July 2021

\begin{abstract}
This comparative study was aimed at estimating analytical behavior of methods for determination of plant available potassium applied to Bulgarian arable soils and to reveal the relationship between the amount of extractable K. Twenty-four samples from two traditional agricultural regions in Bulgaria were studied. Soil potassium was extracted by $\mathrm{NH}_{4} \mathrm{OAc} / \mathrm{HOAc} \mathrm{pH} 4.5$ (AA), diluted double acid (Mehlich 1), $\mathrm{CaCl}_{2}, \mathrm{BaCl}_{2}$ and a modified acetate/lactate method (ALM) and determined by Flame AES. The factors influencing the methods accuracy were identified and uncertainty was estimated. The expanded uncertainty was (in mg $\left.\mathrm{K}_{2} \mathrm{O}\left(100 \mathrm{~g}_{\text {dry soil }}\right)^{-1}\right): 0.10$ (ALM), 0.64 (Mehlich 1), $0.17\left(\mathrm{CaCl}_{2}\right)$ and $1.1(\mathrm{AA})$. The study revealed that the factor which mainly influence the uncertainty of the applied analytical methods for plant available potassium in soil was the calibration of Flame AES determination. The obtained results showed that extractable potassium lowered in the following order $K_{\mathrm{ALM}} \geq K_{\mathrm{AA}}>K_{\mathrm{Mechlich}_{1}}>K_{\mathrm{BaCl}_{2}}>\mathrm{K}_{\mathrm{CaCl}_{2}}$. Soil potassium extracted by ALM procedure correlated with $\mathrm{AA}, \mathrm{BaCl}_{2}-\mathrm{K}, \mathrm{CaCl}_{2}-\mathrm{K}$ and Mehlich $1-\mathrm{K}$ at 0.05 level of significance. ALM extracted between 1.2 to 5.8 times more soil $\mathrm{K}$ than other methods did. The obtained results provided a base for further study on correlation between extractable $\mathrm{K}$ and soil fertility indices for particular soil types and climatic regions in Bulgaria.
\end{abstract}

Keywords: available potassium, extraction methods, Flame AES, uncertainty, arable soils.

\section{INTRODUCTION}

Soil diagnostic is usually based on concentration of potassium, nitrogen and phosphorous, together with $\mathrm{pH}$ and organic carbon determination. Some meso and microelements could also be included for more precise fertilization. The soil nutrients occur in several forms, which put the challenge to choose appropriate extractants and detection finishing of the analysis. Moreover, a multielement analysis is highly demanded to reduce significantly labor, cost and time of analysis.

Potassium exists in soils as water-soluble (soils solution), exchangeable/available, fixed/non-exchangeable and mineral potassium (incorporated in the crystal lattice of mineral and inaccessible for plants). The extracting solution contains a mixture of various reagents that reacts with soil and releases some $\mathrm{K}$ into the solution. Many different extracting solutions have been used worldwide due to variable nature of soil. The Good agricultural practices in Bulgaria implied for fertilization programs based on soil diagnostic by soil analysis [1]. As it has been well recognized no universal soil testing method existed. A given fertilization program should be well reasoned based on field studies in which crop yield response to $K$ fertilizer addition was validated against the amount $\mathrm{K}$ extracted by a specific reagent mixture. Additionally, the instrumental technique for determination of $\mathrm{K}$ in soil extract also influenced the data [2]. Therefore, fertilizer recommendations based on a soil test should be developed for a particular extractant and detection technique $[3,4]$.

Difficulties in comparing the results from various methods for soil analysis for $\mathrm{K}$ determination arose from: (1) different forms of $\mathrm{K}$ in soils; (2) different extraction efficiency of the reagent mixture; (3) variations in the extraction procedure within the same extractants; (4) great diversity of soil nature and thus variation of matrix composition; (5) different detection techniques used to measure $\mathrm{K}$ concentration in soil extract. Nowadays, research on improving the performance of soil testing laboratories and providing sustainable fertilization programs have been constantly intensified. A line of comparative studies on K extraction methods combined with modern statistical and numerical modelling tools proposed conversation between soil test results without loss of validation data [5-10]. Multielement extracting solutions aimed at decreasing analysis costs and labor were proposed [2, 8, 11-13]. The main obstacles come from the different nature of soil and specific response of crops, which implies thorough evaluation of soil testing method for specific region and crop [2, 5, 7, 9].

To correspond to the large variety of arable soil types in Bulgaria, a modified acetate-lactate containing 
extractant, based on Egner-Riehm method was proposed [14]. The method showed increased buffer capacity towards high content of free carbonates commonly encountered in Bulgarian region. The extractant was proved efficient for extraction of plant available potassium and validated for a line of crops $[1,14]$. A recent study showed the possibility of replacement of equilibrium potassium in soil solution with exchangeable potassium by the modified method in estimation of potassium supply and fertilization strategy [15]. The comparison of the data about the fertility status even in a given small region has been hindered as different methods for determination of plant available $\mathrm{K}$ were used [1, 16-19]. Moreover, data about method performance applied to Bulgarian soils could be scarcely found.

The aims of this study were: (1) to reveal the factors which influenced the accuracy of the chosen analytical methods for potassium determination and to estimate uncertainty of measurement; (2) to reveal the relationship between the amount of plant available potassium, extracted by $\mathrm{NH}_{4} \mathrm{OAc} / \mathrm{HOAc}, \mathrm{NaHCO}_{3}$ (Olsen), diluted double acid (Mehlich 1), $\mathrm{CaCl}_{2}, \mathrm{BaCl}_{2}$ and modified acetate-lactate extractant; (3) to demonstrate the relationship between the obtained amount of extractable potassium for Bulgarian arable soils. To our knowledge, the analytical behavior of the modified acetate-lactate based method [14] was presented for the first time.

\section{MATERIALS AND METHODS}

\section{Soil sampling}

The soil samples used in this study were collected from two well-developed agricultural regions in Bulgaria:

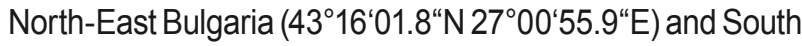
East Bulgaria Thracian valley $\left(42^{\circ} 15^{\prime} 43.0^{\prime \prime} \mathrm{N} 26^{\circ} 16^{\prime} 17.3^{\prime \prime} \mathrm{E}\right)$. Twenty-four arable soil samples were studied, 12 from each region. All samples were collected from a depth of $0-30 \mathrm{~cm}$ by automatic soil sampler following the sampling plan recommended by Nikolova et al. [1]. In average one sample for each 6 ha, each sample was formed from 15-20 individual samples. The samples were stored in plastic bags and transported to the laboratory, where were air dried, ground and sieved through $2 \mathrm{~mm}$ sieve.

\section{Determination of soil characteristics}

Clay content was determined gravimetrically as a fraction below $63 \mu \mathrm{m}$. $\mathrm{pH}$ of the soil samples was determined in water at $1: 2$ (soil-to-liquid ratio) after 1 $\mathrm{h}$ mixing. The samples were left to settle and the $\mathrm{pH}$ was measured using WTW pH-meter equipped with a combined glass electrode.

Electrical conductivity was measured according to the procedure, described in Soil standard testing method [20]: $5 \mathrm{~g}$ of each soil sample were extracted with $25 \mathrm{~mL} \mathrm{~d}$. $\mathrm{H}_{2} \mathrm{O}$ for $1 \mathrm{~h}$. The suspension was left to settle for $10 \mathrm{~min}$ and the electrical conductivity of the supernatant was measured by WTW Multi 3410 electrical conductivity meter, equipped with WTW Tetra Con 925 electrode.

Cation exchange capacity (CEC) was determined according to Hendershot and Duquette [21]. Two $g$ of accurately weighted soil samples were treated with 20.00 $\mathrm{mL}$ of $0.1 \mathrm{M} \mathrm{BaCl}_{2}$ solution. The suspension was stirred for $2 \mathrm{~h}$ and filtered. The filtrate was made up to $100.0 \mathrm{~mL}$ with $\mathrm{d}$. $\mathrm{H}_{2} \mathrm{O}$ and subjected to ICP-OES determination of $\mathrm{Al}, \mathrm{Ca}, \mathrm{K}, \mathrm{Mg}$ and $\mathrm{Na}$. A set of calibration standards at the concentration ranges $5-100 \mu \mathrm{g} \mathrm{L}^{-1}$ or $1-10 \mathrm{mg} \mathrm{L}^{-1}$, according to sample concentrations, were prepared by appropriate dilution of a multi element standard solution ("Ultra scientific", Lot: P00332) containing 24 elements in $5 \% \mathrm{HNO}_{3}$ at concentration $100 \pm 5 \mathrm{mg} \mathrm{L}^{-1}$ of each element. Each standard was scanned at least three times and a mean analytical signal for each component was calculated.

Soil organic carbon was determined after oxidation with $\mathrm{K}_{2} \mathrm{Cr}_{2} \mathrm{O}_{7}$ by back titration with standard solution of Mohr salt (Turin's method). Accurately weighted 0.12 $\mathrm{g}-0.15 \mathrm{~g}$ of soil samples were oxidized by $10.00 \mathrm{~mL}$ $0.0667 \mathrm{M} \mathrm{K}_{2} \mathrm{Cr}_{2} \mathrm{O}_{7}$ (in $1: 2 \mathrm{H}_{2} \mathrm{SO}_{4}$ ) solution with $\mathrm{AgSO}_{4}$ as a catalyst. The samples were homogenized and heated for $20 \mathrm{~min}$ in $160^{\circ} \mathrm{C}$. After cooling, the samples were diluted with distilled water and titrated by $0.2 \mathrm{M}$ standard solution of Mohr salt and $\mathrm{N}$ - phenylanthranilic acid solution as an indicator. Two blank samples (pumice stone) were prepared following the same procedure. The $\mathrm{Fe}\left(\mathrm{NH}_{4}\right)_{2}\left(\mathrm{SO}_{4}\right)_{2}$ solution was standardized against $\mathrm{K}_{2} \mathrm{Cr}_{2} \mathrm{O}_{7}$

Mineral nitrogen $\left(\mathrm{NO}_{3}-\mathrm{N}\right.$ and $\left.\mathrm{NH}_{3}-\mathrm{N}\right)$ was determined after diluted acid extraction at $1: 5$ soil-toliquid ratio for $5 \mathrm{~min}$ followed by spectrophotometric determination of nitrates by cadmium reduction method (Method 8039, Hach Lange) and ammonium by Nessler reaction (Method 8038, Hach Lange).

Available phosphorous was determined spectrophotometrically by the molybdenum blue method after extraction with modified acetate-lactate reagent. Color reagent with ascorbic acid as a reductant was prepared daily by mixing $1.056 \mathrm{~g}$ ascorbic acid and $200 \mathrm{~mL}$ of Murphy-Reilly solution, $12 \mathrm{~g}$ ammonium molybdate, $0.2928 \mathrm{~g}$ potassium antimonyl tartrate in 2 $\mathrm{L} 1.25 \mathrm{M} \mathrm{H}_{2} \mathrm{SO}_{4}$. For $\mathrm{P}_{2} \mathrm{O}_{5}$ determination, $2 \mathrm{~mL}$ of soil extract were mixed with the color reagent and volume was made up to $25 \mathrm{~mL}$ in a measuring flask. After $1 \mathrm{~h}$, the absorbance was measured at $880 \mathrm{~nm}$ against a blank sample by Hach Lange DR 3900 Spectrophotometer. Calibration curve was daily prepared.

\section{Determination of plant available potassium in soil}

Soil potassium was extracted by $\mathrm{NH}_{4} \mathrm{OAc} / \mathrm{HOAc}$ $\mathrm{pH} 4.5$ (AA), diluted double acid (Mehlich 1), $\mathrm{CaCl}_{2}$, $\mathrm{BaCl}_{2}$ and a modified acetate/lactate method (ALM).

$K$ extraction by the modified acetate-lactate method (ALM). A modified acetate-lactate extractant [14] contained $0.1 \mathrm{M}$ calcium lactate, $0.2 \mathrm{M} \mathrm{CH}_{3} \mathrm{COONH}_{4}$ and $0.1 \mathrm{M} \mathrm{HCl}, \mathrm{pH}$ 4.2. All reagents were of p.a. grade, 
produced by Sigma-Aldrich. The $\mathrm{pH}$ of the solution was controlled potentiometrically and if necessary $\mathrm{pH}$ was corrected with aqueous ammonia or acetic acid. Soil $\mathrm{K}$ extraction was carried out for 1 hour at soil-to-liquid ratio $1: 25$ ( $2 \mathrm{~g}$ accurately weighted soil was mixed with $50 \mathrm{~mL}$ extracting solution). The sample was filtered and potassium content was directly measured by flame AES.

Kextraction by Mehlich 1 method. The diluted double acid extracting solution (Mehlich 1) contained $0.05 \mathrm{M} \mathrm{HCl}$ and $0.0125 \mathrm{M} \mathrm{H}_{2} \mathrm{SO}_{4}$. The soil-to-solution ratio was $1: 5$ (10 g of accurately weighted soil samples were mixed with $50 \mathrm{~mL}$ of extracting solution for $5 \mathrm{~min}$ ). Potassium content in the filtered extract was determined by the flame AES.

$\mathrm{K}$ extraction by $\mathrm{CaCl}_{2}$. Five grams accurately weighted soil samples were treated with $50 \mathrm{~mL} 0.01 \mathrm{M}$ $\mathrm{CaCl}_{2}$ solution for $30 \mathrm{~min}$ [22].The obtained extract was sent for flame AES.

Kextraction by $\mathrm{NH}_{4} \mathrm{OAc} / \mathrm{HOAc}$. The extracting solution $0.5 \mathrm{M} \mathrm{NH}_{4} \mathrm{OAc} / \mathrm{HOAc}, \mathrm{pH} 4.5$ was prepared according to [23]. Ten grams of the soil samples were mixed with $50 \mathrm{~mL}$ of the extracting solution for $30 \mathrm{~min}$ and filtered. The solution was analysed by Flame AES.
Potassium determination by Flame Atomic emission spectrometry. Potassium content in the obtained extracts was determined by Jenway PFP7 Flame photometer equipped with interference type color filter and PIN diode detector. The emitted light was measured at $766 \mathrm{~nm}$. Low temperature air/propane gas mixture was used. The airflow was $6 \mathrm{~L} / \mathrm{min}$ at $12 \mathrm{psi}$, sample uptake $4.5 \mathrm{~mL} / \mathrm{min}$. The optimization of flame conditions were made daily to adjust propane gas flow, applying a maximum signal for nominal $\mathrm{K}$ standard as a optimization criterion. The concentration of the nominal standard was chosen depending on the extracting procedure and expected sample concentrations. The same extracting solution was used to set the instrument zero. A calibration curve (readout as a function of concentration of standard solutions) was constructed for each extracting solution at the optimal conditions. During measurements, a nominal standard solution was used to monitor and fine adjusting the optimal flame conditions.

A certified reference material (CRM) containing 1000 mg/L (TraceCert, Lot BCBV7454- Sigma-Aldrich) was used for preparation of calibration standards by appropriate dilution with extracting solutions. A calibration

Sources of uncertainty and expressions used for its calculation

\begin{tabular}{|c|c|}
\hline Expressions used to calculate the uncertainty of the $\mathrm{m}$ & Sources of uncertainty \\
\hline 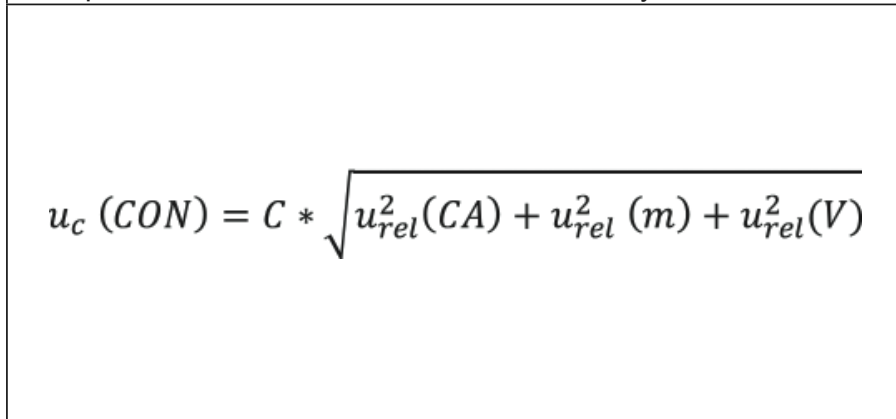 & $\begin{array}{l}u_{c}(C O N) \text { - combined uncertainty; } \\
u_{r e l}(C A) \text { - standard uncertainty associated with } \\
\text { calculation of analyte concentration from calibration } \\
\text { curve; } \\
u_{r e l}(m) \text { - standard uncertainty associated with weighting } \\
\text { the sample aliquot; } \\
u_{r e l}(V) \text { - standard uncertainty associated with } \\
\text { measurement of the volume of the extracting solution } \\
\text { all presented in terms of relative uncertainty; }\end{array}$ \\
\hline$u_{r e l}(C A)=\sqrt{u_{r e}^{2}}$ & $\begin{array}{l}u_{\text {rel }}(\text { Stand }) \text { - standard uncertainty associated with } \\
\text { preparation of calibration standards; } \\
u_{\text {rel }}(\text { Cal }) \text { - standard uncertainty associated with } \\
\text { calibration curve - linear regression; } \\
u_{\text {rel }}(R e p e t) \text { - standard uncertainty obtained in } \\
\text { repeatability conditions; }\end{array}$ \\
\hline$u_{\text {rel }}($ Stand $)=\sqrt{u_{\text {rel }}^{2}(\text { Prim })+u_{\text {rel }}^{2}(\text { Dil })}$ & $\begin{array}{l}u_{\text {rel }}(\text { Prim }) \text { - uncertainty derived from the preparation of } \\
\text { the primary standard solution; } \\
u_{\text {rel }}(D i l) \text { - uncertainty derived from the preparation of the } \\
\text { calibration curve at four concentration levels by diluting } \\
\text { the standard solution; }\end{array}$ \\
\hline$u(C a l)=\frac{1}{b} \sqrt{s_{\text {resid }}^{2} * \frac{1}{n}}+(C i-C m)^{2} * s_{b}^{2}$ & $\begin{array}{l}u_{\text {Cal }} \text { - uncertainty derived from linear least squares } \\
\text { calibration; }\end{array}$ \\
\hline$u($ Repet $)=\frac{s_{S}}{\sqrt{n}}$ & $\begin{array}{l}S_{s} \text { is the standard deviation from the sample replicates; } \\
n \text { is the number of replicates of each sample when } \\
\text { analyzed in routine analysis; }\end{array}$ \\
\hline$U=$ & $\begin{array}{l}U \text { is expanded uncertainty calculated at coverage factor } \\
\text { of } 2(k=2) \text { and } 95 \% \text { confidence level; }\end{array}$ \\
\hline
\end{tabular}


curve in working range specific for each of extractants was prepared: $10-100 \mu \mathrm{g} \mathrm{mL}^{-1} \mathrm{~K}$ in $\mathrm{NH}_{4} \mathrm{OAc} / \mathrm{HOAc}$; $5-20 \mu \mathrm{g} \mathrm{mL}^{-1} \mathrm{~K}$ in acetate-lactate extracting mixture, $5-40 \mu \mathrm{g} \mathrm{mL}^{-1}$ in Mehlich 1 and $5-20 \mu \mathrm{g} \mathrm{mL}^{-1} \mathrm{~K}$ in $\mathrm{CaCl}_{2}$. The studied extraction mixtures were used as blank samples for adjusting the instrument blank. The intensity of the emission of each solution was measured in duplicate and the mean value was used for standard curve construction. The analytical function was obtained applying linear and polynomial regression by least squares method to the obtained data.

Uncertainty and trueness estimation. Method trueness was estimated as bias and relative spike recovery by standard addition of $\mathrm{K}$ solution (certified reference material (CRM) $1000 \mathrm{mg} / \mathrm{L} \pm 4 \mathrm{mg} / \mathrm{L}$ (TraceCert, Lot BCBV7454- Sigma-Aldrich) to the soil sample before extraction. The modified acetate-lactate extraction and flame AES were applied for bias study. An aliquot of standard $\mathrm{KCl}$ solution was added to $2 \mathrm{~g}$ of dry soil, homogenized and stayed to equilibrate for 3 days. Seven replicates were made and the average concentration was used for calculation. Bias was calculated as a difference between content of potassium in the studied soil before and after standard addition. Recovery was calculated as a relative ratio between content of potassium in standard addition obtained after analysis and calculated from the volume and the concentration of standard solution of $\mathrm{KCl}$. The uncertainty of bias was calculated from standard deviation of potassium in soil after standard addition (7 replicates analyzed) according to Cuadros-Rodrıguez et al. [24]. Method uncertainty was estimated according to [24-26]. The sources of uncertainty and the applied equations are presented in Table 1.

Internal Quality control. The instrument performance was monitored applying the following criteria: (1) the photometer reading within $0.05 \%$ of the standard concentration of Quality control standard solution (prepared by appropriate dilution of CRM - TraceCert, Lot BCBV7454); (2) the regression coefficient for the calibration equation $R^{2} \geq 0.98$; (3) the relative standard deviation of a set of three Flame Photometer readings $\leq 3 \%$. If the criteria were not met, the optimization of flame conditions and calibration were renewed.

The method and laboratory performance were monitored by analyzing test soil samples according to EURACHEM/CITAC Guide [25]. The soil samples containing: 22 and $52 \mathrm{mg} \mathrm{K}_{2} \mathrm{O} / 100$ dry soil and used as internal quality control samples, which were analyzed with each batch of measurements. The control charts were constructed and the warning and action limits were set at $\pm 10 \%$ and $\pm 15 \%$ of the mean value, respectively.

Statistical processing of data. Each soil sample was analysed in duplicates. The mean concentration was calculated along with standard deviation at $95 \%$ confidence interval. Correlation analysis was made by Excel Data Analysis tool pack at 0.05 significance level and 22 degree of freedom.

\section{RESULTS AND DISCUSSION}

Estimation of the uncertainty of studied methods for $\mathrm{K}$ determination

The estimation of the uncertainty associated to analytical methods aimed at establishing the comparability of results. In this study the uncertainty was estimated following the modelling approach [24-27]. The measurand was analyte concentration in a soil sample, expressed in $\mathrm{mg} \mathrm{K}_{2} \mathrm{O}(100 \mathrm{~g})^{-1}$. The model equation was:

$$
C=\frac{C A * V * 100 * 1.205}{m * 1000},
$$

where CA was the analyte concentration obtained from the calibration (in $\mathrm{mg} \mathrm{L}^{-1}$ ) and $\mathrm{m}$ was the sample weight (in $\mathrm{g}$ ) and $\mathrm{V}$ was the extract volume (in $\mathrm{mL}$ ), 1.205 was transfer coefficient from $\mathrm{K}$ to $\mathrm{K}_{2} \mathrm{O}$ concentration. The dispersion of results around the true value depended on: - Estimation of the analyte concentration from the calibration curve;

- Measurement of the weight of the sample;

- Measurement of volume of extracting solution.

The sources of uncertainty are presented in Table 1 and the results from uncertainty calculations in Table 2 . As can be seen from the data presented in Table 2, the most influencing factors were calibration and repeatability. It should be pointed out that for more realistic estimation of repeatability the data from samples passed all the stages of analysis were taken. The standard uncertainty in repeatability conditions was estimated on the routine laboratory practice in which 2 parallel samples were analyzed ( $n=2$, Table 1). Thus, if better uncertainty was desired the efforts should be put to improve calibration procedure. The main source of errors was the deviation of calibration curve from linear fit, assessed by correlation coefficient $\left(R^{2}\right)$ and standard deviation of residues $\left(\mathrm{s}_{\text {reg }}\right)$. Higher calibration uncertainty (Table 2) was noticed for $\mathrm{NH}_{4} \mathrm{OAc} / \mathrm{HOAc}$ method in the concentration range 20 $100 \mathrm{mg} \mathrm{K} / \mathrm{L}$ (as presented in the Jenway Protocol [23]). The lowest calibration uncertainty was observed by ALM method: $0.17 \mathrm{mg} \mathrm{L}^{-1}$. To improve the calibration uncertainty polynomial least squares fit was studied. The calibration equations for each of the studied extraction methods are presented in Table 3. Polynomial fit applied to the experimental data resulted in the correlation coefficient $\mathrm{R}^{2}>0.999$ in each of the studied working ranges. The working range for a given extractant was chosen based on the expected concentration of $\mathrm{K}_{2} \mathrm{O}$ in the studied soil samples. However, dilution of the extracts was made if the concentration of $\mathrm{K}$ exceeded the calibration range. In further study, the polynomial fit was applied to calculate the plant available potassium in soil extract.

\section{Estimation of trueness}

The method trueness defined as a "closeness of agreement between the average of an infinite number of replicate measured quantity values and a reference quantity value" and inversely related to systematic measurement error [28] was practically assessed by bias and relative 
Table 2

Uncertainty of $\mathrm{K}$ determination in soils by the studied methods

\begin{tabular}{|c|c|c|c|c|c|c|}
\hline Method & $\begin{array}{l}\text { Sources of } \\
\text { uncertainty }\end{array}$ & $\begin{array}{l}\text { Value } \\
\qquad x\end{array}$ & $\begin{array}{c}\text { Standard } \\
\text { Uncertainty } \\
u(x)\end{array}$ & $\begin{array}{c}\text { Relative } \\
\text { Standard } \\
\text { Uncertainty } \\
u(x) / x\end{array}$ & $\begin{array}{c}\text { Combined } \\
\text { Uncertainty } \\
u_{c}\end{array}$ & $\begin{array}{c}\text { Expanded } \\
\text { Uncertainty } \\
U\end{array}$ \\
\hline \multirow{4}{*}{ ALM } & $\begin{array}{l}\text { Linear least } \\
\text { squares calibration }\end{array}$ & $\begin{array}{c}10 \\
\mathrm{mg} \mathrm{L}^{-1}\end{array}$ & $\begin{array}{c}0.17 \\
\mathrm{mg} \mathrm{L}^{-1}\end{array}$ & 0.017 & \multirow{4}{*}{$\begin{array}{c}0.049 \\
\mathrm{mg}(100 \mathrm{~g})^{-1}\end{array}$} & \\
\hline & Repeatability & $\begin{array}{c}28 \\
\mathrm{mg}(100 \mathrm{~g})^{-1}\end{array}$ & 0.84 & 0.03 & & \\
\hline & $\begin{array}{l}\text { Concentration } \\
\text { of the standard } \\
\text { solutions }\end{array}$ & $\begin{array}{c}10 \\
\mathrm{mg} \mathrm{L}^{-1}\end{array}$ & $\begin{array}{l}0.025 \\
\mathrm{mg} \mathrm{L}^{-1}\end{array}$ & 0.0025 & & $\begin{array}{c}0.10 \\
\mathrm{mg}(100 \mathrm{~g})^{-1}\end{array}$ \\
\hline & $\begin{array}{l}\text { Concentration of } \\
\text { sample in extract } \\
\text { solution }\end{array}$ & $\begin{array}{c}0.04 \\
\mathrm{~g} \mathrm{~mL}^{-1}\end{array}$ & $\begin{array}{c}0.00023 \\
\mathrm{~g} \mathrm{~mL}^{-1}\end{array}$ & 0.0058 & & \\
\hline \multirow{4}{*}{ Mehlich 1} & $\begin{array}{c}\text { Linear least } \\
\text { squares calibration }\end{array}$ & $\begin{array}{c}10 \\
\mathrm{mg} \mathrm{L}^{-1}\end{array}$ & $\begin{array}{c}1.4 \\
\mathrm{mg} \mathrm{L}^{-1}\end{array}$ & $\begin{array}{c}0.14 \\
\mathrm{mg} \mathrm{L}^{-1}\end{array}$ & \multirow{4}{*}{\multicolumn{2}{|c|}{$\begin{array}{c}0.31 \\
\mathrm{mg}(100 \mathrm{~g})^{-1} \\
0.64 \\
\mathrm{mg}(100 \mathrm{~g})^{-1}\end{array}$}} \\
\hline & Repeatability & $\begin{array}{c}10 \\
\mathrm{mg}(100 \mathrm{~g})^{-1}\end{array}$ & 0.73 & 0.073 & & \\
\hline & $\begin{array}{l}\text { Concentration of } \\
\text { the standard stock } \\
\text { solution }\end{array}$ & $\begin{array}{c}10 \\
\mathrm{mg} \mathrm{L}^{-1}\end{array}$ & $\begin{array}{l}0.025 \\
\mathrm{mg} \mathrm{L}^{-1}\end{array}$ & 0.0025 & & \\
\hline & $\begin{array}{c}\text { Concentration of } \\
\text { sample in extract } \\
\text { solution }\end{array}$ & $\begin{array}{c}0.2 \\
\mathrm{~g} \mathrm{~mL}^{-1}\end{array}$ & 0.0023 & 0.012 & & \\
\hline \multirow{4}{*}{$\mathrm{CaCl}_{2}$} & $\begin{array}{c}\text { Linear least } \\
\text { squares calibration }\end{array}$ & $\begin{array}{c}10 \\
\mathrm{mg} \mathrm{L}^{-1}\end{array}$ & $\begin{array}{c}0.75 \\
\mathrm{mg} \mathrm{L}^{-1}\end{array}$ & $\begin{array}{c}0.08 \\
\mathrm{mg} \mathrm{L}^{-1}\end{array}$ & \multirow{4}{*}{\multicolumn{2}{|c|}{$\begin{array}{c}0.085 \\
\mathrm{mg}(100 \mathrm{~g})^{-1} \\
0.17 \\
\mathrm{mg}(100 \mathrm{~g})^{-1}\end{array}$}} \\
\hline & Repeatability & $\begin{array}{c}5 \\
\mathrm{mg}(100 \mathrm{~g})^{-1}\end{array}$ & 0.4 & 0.08 & & \\
\hline & $\begin{array}{l}\text { Concentration of } \\
\text { the standard stock } \\
\text { solution }\end{array}$ & $\begin{array}{c}10 \\
\mathrm{mg} \mathrm{L}^{-1}\end{array}$ & $\begin{array}{l}0.025 \\
\mathrm{mg} \mathrm{L}^{-1}\end{array}$ & 0.0025 & & \\
\hline & $\begin{array}{l}\text { Concentration of } \\
\text { sample in extract } \\
\text { solution }\end{array}$ & $\begin{array}{c}0.1 \\
\mathrm{~g} \mathrm{~mL}^{-1}\end{array}$ & 0.0006 & 0.0057 & & \\
\hline \multirow{4}{*}{$\mathrm{AA}$} & $\begin{array}{c}\text { Linear least } \\
\text { squares calibration }\end{array}$ & $\begin{array}{c}60 \\
\mathrm{mg} \mathrm{L}^{-1}\end{array}$ & $\begin{array}{c}32 \\
\mathrm{mg} \mathrm{L}^{-1}\end{array}$ & $\begin{array}{l}0.53 \\
\mathrm{mg} \mathrm{L}^{-1}\end{array}$ & \multirow{4}{*}{\multicolumn{2}{|c|}{$\begin{array}{c}0.57 \\
\mathrm{mg}(100 \mathrm{~g})^{-1} \\
1.1 \\
\mathrm{mg}(100 \mathrm{~g})^{-1}\end{array}$}} \\
\hline & Repeatability & $\begin{array}{c}28 \\
\mathrm{mg}(100 \mathrm{~g})^{-1}\end{array}$ & 0.94 & 0.03 & & \\
\hline & $\begin{array}{l}\text { Concentration of } \\
\text { the standard stock } \\
\text { solution }\end{array}$ & $\begin{array}{c}60 \\
\mathrm{mg} \mathrm{L}^{-1}\end{array}$ & $\begin{array}{l}0.025 \\
\mathrm{mg} \mathrm{L}^{-1}\end{array}$ & 0.0025 & & \\
\hline & $\begin{array}{l}\text { Concentration of } \\
\text { sample in extract } \\
\text { solution }\end{array}$ & $\begin{array}{c}0.2 \\
\mathrm{~g} \mathrm{~mL}^{-1}\end{array}$ & 0.0006 & 0.0001 & & \\
\hline
\end{tabular}

Table 3

Calibration equations of the studied methods for determination of plant available potassium by Flame AES after different extraction procedures

\begin{tabular}{|c|c|c|c|c|c|}
\hline Method & Concenrtation range $(\mathrm{mg} \mathrm{K/L})$ & $\mathrm{N}$ & Equation & $R^{2}$ & $n$ \\
\hline ALM & $5 \div 20$ & 4 & $y=-0.0053 x^{2}+1.1255 x+1.162$ & 0.9999 & 6 \\
\hline Mehlich 1 & $5 \div 40$ & 5 & $y=-0.0089 x^{2}+1.3795 x+0.767$ & 0.9996 & 3 \\
\hline $\mathrm{AA}$ & $20 \div 100$ & 5 & $y=-0.0036 x^{2}+1.2690 x+11.553$ & 0.9992 & 6 \\
\hline $\mathrm{CaCl}_{2}$ & $5 \div 20$ & 4 & $y=-0.0213 x^{2}+1.6776 x+0.550$ & 0.9998 & 2 \\
\hline
\end{tabular}

$N$ - number of calibration points, $n$ - number of calibration runs, $R-$ correlation coefficient. 
spike recovery [25, 29]. A standard addition approach was applied in two variants: (1) to assess method bias - the standard addition of potassium CRM solution before extraction and (2) to assess measurement bias - standard addition potassium CRM after extraction and before measurement $[25,29,30]$. The advantage of the applied approach was that it allowed the trueness to be evaluated in sample types usually encountered in the laboratory. It is well recognized that the efficiency of extracting solution depends not only on its composition and procedure used, but on the soil type and its physical and chemical properties [1, 31]. Thus, soil matrix varied widely from sample to sample and trueness estimation could be widely influenced. As a drawback, it should be noted that the spiked potassium could not reach full equilibrium with the soil sample and the obtained bias appeared approximate estimate of bias in available potassium in soil $[25,29,30]$. The defined volume of standard $\mathrm{KCl}$ solution was added to studied soils and let to equilibrate for 3 days. The spiked soils were subjected to full extraction-determination procedure by ALM and flame AES. The obtained average bias was $1.49 \mathrm{mg} \mathrm{K}_{2} \mathrm{O}(100 \mathrm{~g})^{-1}$ dry soil, corresponding to $111 \%$ recovery. The uncertainty of associated to the recovery was $0.03 \mathrm{mg} \mathrm{K}_{2} \mathrm{O}(100 \mathrm{~g})^{-1}$ calculated according to [24]. The hypothesis of no bias correction was assumed and the bias was included in the combined uncertainty: $u_{c}=$ $1.6 \mathrm{mg} \mathrm{K}_{2} \mathrm{O}$ (100 g dry soil) $)^{-1}$ and expanded uncertainty: $3.3 \mathrm{mg} \mathrm{K}_{2} \mathrm{O}$ (100 $\mathrm{g}$ dry soil $)^{-1}$.

\section{Assessment of soil characteristics}

The results from analysis of 24 agricultural (arable) soil samples from two regions in Bulgaria are presented in Table 4. Active acidity (in $\mathrm{H}_{2} \mathrm{O}$ ), organic carbon content, cation exchange capacity, main nutrients content, exchangeable $\mathrm{Na}^{+}, \mathrm{K}^{+}, \mathrm{Ca}^{2+}, \mathrm{Mg}^{2+}$ and $\mathrm{Al}^{3+}$, as well as clay fractions were determined. The soils $\mathrm{pH}$ varied between 6.97 - 8.40. CEC in all studied samples was between

Table 4

Characterization of topsoil properties

\begin{tabular}{|c|c|c|c|c|c|c|c|c|c|c|c|c|}
\hline \multirow{2}{*}{ Sample } & \multirow{2}{*}{$\mathrm{pH}$} & \multirow{2}{*}{$\begin{array}{c}E C, \\
\mu S / c m\end{array}$} & \multirow{2}{*}{$\begin{array}{c}\text { CEC, } \\
\text { cmolc/kg }\end{array}$} & \multicolumn{5}{|c|}{ Exchangeable ions, $\mathrm{mg} / \mathrm{kg}$} & \multirow{2}{*}{$\begin{array}{c}\text { orgainc } \\
\text { C, \% }\end{array}$} & \multirow{2}{*}{$\begin{array}{c}\text { Ex- } \\
\text { changea- } \\
\text { ble } \mathrm{PO}_{4}{ }^{3-}, \\
\mathrm{mg} / \mathrm{kg}\end{array}$} & \multirow{2}{*}{$\begin{array}{l}\Sigma \mathrm{NO}^{3-} \\
+\mathrm{NH}^{4+}, \\
\mathrm{mg} / \mathrm{kg}\end{array}$} & \multirow{2}{*}{$\begin{array}{c}\text { Clay } \\
\text { fraction, } \\
\%\end{array}$} \\
\hline & & & & $\mathrm{Na}^{+}$ & $\mathrm{K}^{+}$ & $\mathrm{Ca}^{2+}$ & $\mathrm{Mg}^{2+}$ & $\mathrm{Al}^{3+}$ & & & & \\
\hline \multicolumn{13}{|c|}{ Region 1} \\
\hline $1 \mathrm{R}$ & 6.94 & 185 & 36.9 & 5.2 & 12.6 & 649 & 49.6 & 0.1 & 2.48 & 56 & 14 & 15 \\
\hline $2 \mathrm{R}$ & 7.38 & 172 & 37.7 & 7.4 & 7.7 & 662 & 53.5 & 0.2 & 2.39 & 74 & 12 & 18 \\
\hline $3 R$ & 7.53 & 191 & 32.2 & 5.4 & 13.5 & 569 & 40.7 & 0.1 & 2.61 & 98 & 16 & 28 \\
\hline $4 \mathrm{R}$ & 7.52 & 191 & 39 & 13.9 & 7.6 & 660 & 70.2 & 0.1 & 3.35 & 44 & 19 & 15 \\
\hline $5 \mathrm{R}$ & 7.4 & 798 & 37.5 & 54.7 & 10.9 & 573 & 102 & 0.2 & 2.65 & 59 & 13 & 16 \\
\hline $6 \mathrm{R}$ & 7.42 & 1214 & 36.8 & 68 & 8 & 550 & 109 & 0.7 & 2.96 & 50 & 13 & 15 \\
\hline $7 \mathrm{R}$ & 7.68 & 296 & 20.1 & 47.3 & 5 & 317 & 49.5 & 0.1 & 0.98 & 40 & 5 & 22 \\
\hline $8 \mathrm{R}$ & 7.54 & 181 & 29.2 & 5.4 & 16.2 & 520 & 33.2 & 0.2 & 1.65 & 157 & 10 & 25 \\
\hline $9 \mathrm{R}$ & 6.97 & 105 & 23.5 & 8.5 & 16.2 & 373 & 53 & 10.8 & 2.69 & 21 & 26 & 29 \\
\hline $10 \mathrm{R}$ & 6.47 & 97 & 21.9 & 4.8 & 18.2 & 350 & 47 & 1.5 & 2.8 & 42 & 21 & 26 \\
\hline $11 \mathrm{R}$ & 7.21 & 182 & 33 & 3.9 & 8.6 & 596 & 35.6 & $<0.02$ & 2.64 & 46 & 12 & 22 \\
\hline $12 \mathrm{R}$ & 7.67 & 163 & 35.8 & 3.4 & 7.9 & 649 & 37.6 & 0.3 & 1.93 & 114 & 6 & 15 \\
\hline $\max$ & 7.7 & 1214 & 39.0 & 68 & 18.2 & 662 & 109 & 10.8 & 3.35 & 157 & 26 & 29 \\
\hline $\min$ & 6.5 & 97 & 20.1 & 3.4 & 5 & 317 & 33.2 & 0.1 & 0.98 & 21 & 5 & 15 \\
\hline median & 7.4 & 183 & 34.4 & 6.4 & 9.75 & 571 & 49.55 & 0.2 & 2.63 & 53 & 13 & 20 \\
\hline mean & 7.3 & 314 & 32.0 & 19.0 & 11.0 & 539 & 56.7 & 1.3 & 2.43 & 67 & 14 & 21 \\
\hline $\mathrm{N}$ & 12 & 12 & 12 & 12 & 12 & 12 & 12 & 12 & 12 & 12 & 12 & 12 \\
\hline \multicolumn{13}{|c|}{ Region 2} \\
\hline $1 \mathrm{~F}$ & 7.49 & 151 & 24.6 & 2.3 & 13.8 & 466 & 10.5 & $<0.05$ & 2.8 & 92 & 13 & 29 \\
\hline $2 \mathrm{~F}$ & 7.84 & 133 & 24.4 & 3.1 & 15.4 & 463 & 10.7 & $<0.05$ & 2.17 & 95 & 12 & 21 \\
\hline $3 F$ & 8.05 & 169 & 20.5 & 3.4 & 24.7 & 380 & 10.8 & $<0.05$ & 2.56 & 137 & 13 & 21 \\
\hline $4 \mathrm{~F}$ & 7.88 & 166 & 25.4 & 3.9 & 24.1 & 476 & 12.4 & $<0.05$ & 3.02 & 95 & 7 & 39 \\
\hline $5 F$ & 7.42 & 147 & 24.7 & 2.5 & 17.1 & 470 & 9.4 & $<0.05$ & 2.87 & 97 & 16 & 38 \\
\hline $6 \mathrm{~F}$ & 7.57 & 308 & 24.9 & 2.7 & 12.5 & 474 & 9.8 & $<0.05$ & 2.66 & 70 & 21 & 48 \\
\hline $7 F$ & 7.67 & 140 & 17.4 & 3 & 12.1 & 333 & 4.6 & $<0.05$ & 4.04 & 163 & 12 & 56 \\
\hline
\end{tabular}




\begin{tabular}{|c|c|c|c|c|c|c|c|c|c|c|c|c|}
\hline $8 \mathrm{~F}$ & 7.76 & 129 & 17.8 & 2.3 & 13.8 & 340 & 5.3 & $<0.05$ & 3.9 & 87 & 16 & 39 \\
\hline $9 \mathrm{~F}$ & 7.75 & 143 & 21.8 & 2.5 & 19.5 & 417 & 6 & 1.3 & 4.12 & 133 & 17 & 27 \\
\hline $10 \mathrm{~F}$ & 7.89 & 195 & 32.1 & 3 & 10.8 & 623 & 8.5 & 0.5 & 4.02 & 36 & 17 & 20 \\
\hline $11 \mathrm{~F}$ & 8.26 & 162 & 28.5 & 2.4 & 12.4 & 543 & 12.7 & 0.1 & 1.61 & 175 & 10 & 41 \\
\hline $12 \mathrm{~F}$ & 8.4 & 177 & 34.5 & 2.6 & 20 & 654 & 15.5 & 0.5 & 1.65 & 586 & 13 & 35 \\
\hline $\max$ & 8.4 & 308 & 34.5 & 3.9 & 24.7 & 654 & 15.5 & 1.3 & 4.12 & 586 & 21 & 56 \\
\hline $\min$ & 7.4 & 129 & 17.4 & 2.3 & 10.8 & 333 & 4.6 & 0.1 & 1.61 & 36 & 7 & 20 \\
\hline median & 7.8 & 156 & 24.7 & 2.65 & 14.6 & 468 & 10.2 & 0.5 & 2.84 & 96 & 13 & 37 \\
\hline mean & 7.8 & 168 & 24.7 & 2.8 & 16.4 & 469.9 & 9.7 & 0.6 & 2.95 & 147 & 14 & 35 \\
\hline $\mathrm{N}$ & 12 & 12 & 12 & 12 & 12 & 12 & 12 & 12 & 12 & 12 & 12 & 12 \\
\hline \multicolumn{13}{|c|}{ Region 1 and 2} \\
\hline $\max$ & 8.4 & 1214 & 39 & 68 & 24.7 & 662 & 109 & 10.8 & 4.12 & 586 & 26 & 56 \\
\hline $\min$ & 6.5 & 97.2 & 17.4 & 2.3 & 5 & 317 & 4.6 & 0.1 & 0.98 & 21 & 5 & 15 \\
\hline median & 7.6 & 170.4 & 27.0 & 3.7 & 13.1 & 498 & 24.4 & 0.2 & 2.66 & 90 & 13 & 26 \\
\hline mean & 7.6 & 241.3 & 28.3 & 10.9 & 13.7 & 504 & 33.2 & 1.1 & 2.69 & 107 & 14 & 28 \\
\hline $\mathrm{N}$ & 24 & 24 & 24 & 24 & 24 & 24 & 24 & 24 & 24.00 & 24 & 24 & 24 \\
\hline
\end{tabular}

$18-39 \mathrm{cmol}^{-1} \mathrm{~kg}^{-1}$. Organic carbon varied between 1.6 and $4.2 \%$. The studied soils presented different fertility indices according to the classification based on the modified acetate-lactate method and accepted in Bulgaria: $30 \%$ very high, $33 \%$ high, $33 \%$ medium and $4 \%$ very low. The studied soils were chosen, from one hand, to present different soil characteristics, and from other - to study the performance of double acid method (Mehlich 1) in neutral or alkaline samples with CEC $>10 \mathrm{cmol}_{\mathrm{c}} \mathrm{kg}^{-1}$. The interest was provoked by the contradiction in the published data. First, Mehlich 1 method was designed for acidic soils with low CEC from Florida, USA $\left(\mathrm{pH}<6.5\right.$ and CEC $\left.<10 \mathrm{mgeq} \mathrm{kg}^{-1}\right)$ [32]. However, Hosseinpur and Samavati [12] found that Mehlich 1 well correlated with other methods for calcareous soils from Hamedan region, Iran. Considering the fact, that Mehlich 1 was fast, cheap and easy to apply we were interested to study its effectiveness on selected Bulgarian arable soils.

\section{Comparison of extractable potassium by the studied methods}

The plant available $\mathrm{K}$ estimated by Mehlich 1 , a modified acetate-lactate procedure (ALM), $\mathrm{NH}_{4} \mathrm{OAcl}$ $\mathrm{HOAc}(\mathrm{AA}), \mathrm{CaCl}_{2}, \mathrm{BaCl}_{2}$ and Olsen methods were studied. The results for extractable potassium in soil, expressed as $\mathrm{mg} \mathrm{K}_{2} \mathrm{O} / 100 \mathrm{~g}$ dry soil, and the fertility status of the studied soils are presented in Table 5 and Table 6. A comparison between the amount of extractable potassium is illustrated on Figure. The results from Olsen method $\left(0.5 \mathrm{M} \mathrm{NaHCO}_{3}\right)$ were not presented as the obtained extracts were not suitable for Flame AES determination of potassium due to some interferences.

CEC was determined by Hendershot and Duquette method [21] after extraction with $\mathrm{BaCl}_{2}$ and ICP-AES determination, thus providing data about potassium in extract. As can be seen from the data, $\mathrm{BaCl}_{2}$ extracted more potassium than $\mathrm{CaCl}_{2}$ due to the higher concentration of $\mathrm{Ba}^{2+}$ and 1 : 10 soil-to-liquid ratio, as well as to higher sensitivity of ICP-OES measurement.

Two soil-to-liquid ratios were studied with Mehlich 1 reagent. It was noticed that in calcareous soils with $\mathrm{pH}>7.5$ the acidity of extractant was lowered due to neutralization with carbonates. The $\mathrm{pH}$ of extract was higher than 4.5 and reached 7 in some samples. In contrast, extract of soils samples with $\mathrm{pH}<7$ kept the original level of acidity of Mehlich 1 extractant $(\mathrm{pH}<2.5)$. Thus, Mehlich 1 reagent did not guarantee the same conditions of extraction in different types of soils, which could affect the parts of extracted potassium. In attempt to overcome changes in extraction conditions, two series of experiments were conducted: (1) increasing soil-to-liquid ratio up to $1: 10$ with the same concentration of acids and (2) doubled concentration of Mehlich 1 extractant with the same soil-to-liquid ratio $(1: 5)$. Increased soilto-liquid ratio $(1: 10)$ preserved the $\mathrm{pH}$ of extractant in the majority of calcareous soils, the obtained extract was clear and suitable not only for $\mathrm{K}$ determination by Flame AES, but for spectrophotometric determination of other nutrients. In the second series of experiment, the increased concentration of acids in the extraction mixture resulted in unchanged $\mathrm{pH}$, but the obtained solution was unclear and needed additional treatment with charcoal before the measurement. As the results showed, the increased soil-to-liquid ratio was better approach to keep extraction conditions and to obtain the same part of available potassium extracted. It was in contrast to observations made by Quin et al. [33] that the increased soil-extractant ratio did not improve the results.

The results in Table 6 and Figure demonstrated that the amount of total and extractable $\mathrm{K}$ varied widely with the method used. It was shown that in the same soil sample, the content of exchanging potassium species varied greatly when using different extraction methods: from 4.3 to 10.1 times (Region 1) and from 3.2 to 10.9 times (Region 2). Of the tested methods, ALM extracted 
Table 5

Extractable potassium determined by different extractants and Flame AES and corresponding fertility indices ( ${ }^{\mathrm{a}}[1]$; ${ }^{\mathrm{b}}$ [35]); c [23]; [4]). Standard deviations of 2 parallel samples are presented in the brackets next to the mean value

\begin{tabular}{|c|c|c|c|c|c|c|c|c|c|}
\hline \multirow{2}{*}{ Sample } & \multicolumn{9}{|c|}{$\mathrm{K}_{2} \mathrm{O}, \mathrm{mg}(100 \mathrm{~g})^{-1}$} \\
\hline & ALM & Fertility $^{a}$ & Mehlich 1 & Fertility $^{b}$ & $\mathrm{CaCl}_{2}$ & Fertility $^{c}$ & $\mathrm{NH}_{4} \mathrm{Ac} / \mathrm{HAc}$ & Fertility $^{d}$ & $\mathrm{BaCl}_{2}$ \\
\hline \multicolumn{10}{|c|}{ Region 1} \\
\hline $1 \mathrm{R}$ & $38.8_{(0.2)}$ & very high & $8.0_{(1.3)}$ & high & $5.1_{(0.1)}$ & low & $\left.31.1_{(0.86}\right)$ & very low & $15.2_{(0.1)}$ \\
\hline $2 \mathrm{R}$ & $22.8_{(0.5)}$ & medium & $3.4_{(0.3)}$ & low & $2.5_{(0.1)}$ & low & $22.3_{(0.8)}$ & very low & $9.3_{(0.4)}$ \\
\hline $3 R$ & $50.3_{(0.9)}$ & very high & $7.7_{(1.8)}$ & high & $6.5_{(0.04)}$ & low & $39.8_{(0.2)}$ & low & $16.3_{(0.3)}$ \\
\hline $4 \mathrm{R}$ & $24.7_{(0.2)}$ & medium & $6.3_{(0.7)}$ & medium & $3.0_{(0.1)}$ & low & $23.3_{(1.0)}$ & very low & $9.2_{(0.8)}$ \\
\hline $5 R$ & $36.3_{(0.5)}$ & high & $6.6_{(0.1)}$ & medium & $4.1_{(0.2)}$ & low & $32.0_{(0.7)}$ & very low & $13.2_{(1.1)}$ \\
\hline $6 \mathrm{R}$ & $28.2_{(0.4)}$ & medium & $6.1_{(1.0)}$ & medium & $2.8_{(0.1)}$ & low & $23.7_{(0.8)}$ & very low & $9.7_{(0.1)}$ \\
\hline $7 \mathrm{R}$ & $14.1_{(0.6)}$ & low & $1.8_{(0.7)}$ & low & $1.5_{(0.6)}$ & low & $13.1_{(0.7)}$ & very low & $6.1_{(0.7)}$ \\
\hline $8 \mathrm{R}$ & $43.1_{(1.0)}$ & very high & $7.2_{(3.3)}$ & high & $5.4_{(0.04)}$ & low & $35.7_{(0.8)}$ & very low & $19.5_{(1.4)}$ \\
\hline $9 \mathrm{R}$ & $36.0_{(1.5)}$ & high & $13.7_{(1.9)}$ & very high & $5.7_{(0.3)}$ & low & $27.5_{(0.6)}$ & very low & $16.0_{(0.2)}$ \\
\hline $10 \mathrm{R}$ & $43.7_{(1.2)}$ & very high & $17.1_{(2.1)}$ & very high & $10.1_{(1.3)}$ & low & $43.5_{(2.4)}$ & low & $15.6_{(0.3)}$ \\
\hline $11 \mathrm{R}$ & $27.0_{(1.6)}$ & medium & $3.9_{(2.0)}$ & medium & $2.7_{(0.2)}$ & low & $24.5_{(0.8)}$ & very low & $10.4_{(0.6)}$ \\
\hline $12 \mathrm{R}$ & $30.2_{(0.9)}$ & high & $3.5_{(0.7)}$ & medium & $3.3_{(0.2)}$ & low & $26.6_{(0.1)}$ & very low & $9.5_{(0.4)}$ \\
\hline $\max$ & 50.3 & & 17.1 & & 10.1 & & 43.5 & & 19.5 \\
\hline $\min$ & 14.1 & & 1.8 & & 1.5 & & 13.1 & & 6.1 \\
\hline median & 33.1 & & 6.5 & & 3.7 & & 27.0 & & 11.8 \\
\hline mean & 32.9 & & 7.1 & & 4.4 & & 28.6 & & 12.5 \\
\hline $\mathrm{N}$ & 12 & & 12 & & 12 & & 12 & & 12 \\
\hline \multicolumn{10}{|c|}{ Region 2} \\
\hline $1 \mathrm{~F}$ & $38.8_{(0.4)}$ & high & $7.2_{(0.7)}$ & high & $5.3_{(0.1)}$ & low & $26.3_{(1.0)}$ & very low & $14.7_{(0.1)}$ \\
\hline $2 \mathrm{~F}$ & $31.5_{(0.5)}$ & high & $6.0_{(0.9)}$ & medium & $6.4_{(0.03)}$ & low & $26.5_{(1.0)}$ & very low & $8.6_{(0.8)}$ \\
\hline $3 F$ & $57.7_{(0.3)}$ & very high & $13.7_{(1.4)}$ & very high & $14.0_{(1.2)}$ & low & $45.3_{(1.0)}$ & low & $15.6_{(0.3)}$ \\
\hline $4 \mathrm{~F}$ & $49.5_{(0.1)}$ & very high & $9.9_{(2.2)}$ & high & $10.0_{(1.3)}$ & low & $29.4_{(1.0)}$ & very low & $9.1_{(0.9)}$ \\
\hline $5 F$ & $39.5_{(0.5)}$ & high & $6.5_{(2.3)}$ & medium & $7.4_{(1.0)}$ & low & $29.8_{(1.0)}$ & very low & $12.9_{(0.2)}$ \\
\hline $6 \mathrm{~F}$ & $27.5_{(0.7)}$ & medium & $5.5_{(0.3)}$ & medium & $5.0_{(0.1)}$ & low & $23.8_{(0.8)}$ & very low & $8.7_{(0.4)}$ \\
\hline $7 F$ & $43.2_{(0.3)}$ & very high & $7.9_{(1.9)}$ & high & $5.4_{(0.1)}$ & low & $20.3_{(0.4)}$ & very low & $9.7_{(0.1)}$ \\
\hline $8 \mathrm{~F}$ & $32.3_{(0.5)}$ & medium & $6.0_{(0.9)}$ & medium & $6.3_{(0.7)}$ & low & $23.1_{(0.8)}$ & very low & $9.0_{(0.9)}$ \\
\hline $9 \mathrm{~F}$ & $26.1_{(0.1)}$ & medium & $2.7_{(1.7)}$ & low & $8.4_{(0.1)}$ & low & $27.4_{(0.6)}$ & very low & $22.3_{(1.0)}$ \\
\hline $10 \mathrm{~F}$ & $28.0_{(0.9)}$ & medium & $7.5_{(1.7)}$ & high & $2.1_{(0.1)}$ & low & $22.9_{(1.0)}$ & very low & $10.4_{(0.6)}$ \\
\hline $11 \mathrm{~F}$ & $17.4_{(0.3)}$ & medium & $3.5_{(1.2)}$ & medium & $3.4_{(0.2)}$ & low & $26.7_{(0.1)}$ & very low & $6.3_{(0.7)}$ \\
\hline $12 \mathrm{~F}$ & $25.9_{(0.7)}$ & high & $6.3_{(0.4)}$ & medium & $6.0_{(0.8)}$ & low & $26.5_{(1.0)}$ & very low & $19.8_{(1.3)}$ \\
\hline $\max$ & 57.7 & & 13.7 & & 14.0 & & 45.3 & & 22.3 \\
\hline $\min$ & 17.4 & & 2.7 & & 2.1 & & 20.3 & & 6.3 \\
\hline median & 31.9 & & 6.4 & & 6.2 & & 26.5 & & 10.1 \\
\hline mean & 34.8 & & 6.9 & & 6.6 & & 27.3 & & 12.2 \\
\hline $\mathrm{N}$ & 12 & & 12 & & 12 & & 12 & & 12 \\
\hline \multicolumn{10}{|c|}{ Region 1 and 2} \\
\hline $\max$ & 57.7 & & 17.1 & & 14.0 & & 45.3 & & 22.3 \\
\hline $\min$ & 14.1 & & 1.8 & & 1.5 & & 13.1 & & 6.1 \\
\hline median & 31.9 & & 6.4 & & 5.4 & & 26.5 & & 10.4 \\
\hline mean & 33.9 & & 7.0 & & 5.5 & & 28.0 & & 12.4 \\
\hline $\mathrm{N}$ & 24 & & 24 & & 24 & & 24 & & 24 \\
\hline
\end{tabular}

the highest amount of $\mathrm{K}$ (mean $33.4 \mathrm{mg} \mathrm{K}_{2} \mathrm{O} / 100 \mathrm{~g}$, median $31.9 \mathrm{mg} \mathrm{K} \mathrm{K}_{2} \mathrm{O} 100 \mathrm{~g}$, ranged $14.1-57.7 \mathrm{mg}$ $\mathrm{K}_{2} \mathrm{O} / 100 \mathrm{~g}$ ) and $\mathrm{CaCl}_{2}$ removed the lowest amount of $\mathrm{K}$ (mean $5.6 \mathrm{mg} \mathrm{K}_{2} \mathrm{O} / 100 \mathrm{~g}$, median $5.4 \mathrm{mg} \mathrm{K}_{2} \mathrm{O} / 100 \mathrm{~g}$, ranged 1.5-14.0 $\mathrm{mg} \mathrm{K}_{2} \mathrm{O} / 100 \mathrm{~g}$ ). On average ALM extracted 1.2, 3.1, 4.8, and 5.9 times more $\mathrm{K}$ than did $\mathrm{AA}, \mathrm{BaCl}_{2}$, Mehlich 1 and $\mathrm{CaCl}_{2}$, respectively. As can be seen ALM and AA extracted almost the same amount of $K$ 
Table 6

Soil potassium fertility indices applied in this study

\begin{tabular}{|c|c|c|c|}
\hline Method & $\begin{array}{c}\mathrm{K}_{2} \mathrm{O} \\
\mathrm{mg} / 100 \mathrm{~g}\end{array}$ & $\begin{array}{c}\text { Fertility } \\
\text { index }\end{array}$ & $\begin{array}{l}\text { Refer- } \\
\text { ences }\end{array}$ \\
\hline \multirow{5}{*}{ ALM } & $<12$ & very low & \multirow{5}{*}{ [1] } \\
\hline & $13-16$ & low & \\
\hline & $17-28$ & medium & \\
\hline & $29-38$ & high & \\
\hline & $>38$ & very high & \\
\hline \multirow{5}{*}{ Mehlich 1} & $<1.5$ & very low & \multirow{5}{*}{ [34] } \\
\hline & $1.5-3.5$ & low & \\
\hline & $3.5-7$ & medium & \\
\hline & $7-13$ & high & \\
\hline & $>13$ & very high & \\
\hline \multirow{5}{*}{$\mathrm{NH}_{4} \mathrm{OAc}(\mathrm{HOAc})$} & $0-36$ & Very low & \multirow{5}{*}{ [23] } \\
\hline & $37-72$ & Low & \\
\hline & $73-145$ & Medium & \\
\hline & $146-241$ & High & \\
\hline & $>242$ & Very high & \\
\hline \multirow{4}{*}{$\mathrm{CaCl}_{2}$} & $<15$ & Low & \multirow{4}{*}{ [4] } \\
\hline & $15-25$ & Medium & \\
\hline & $25-80$ & High & \\
\hline & $>80$ & Exessive & \\
\hline
\end{tabular}

(Table 6). The possible explanation of this observation could be found in similarity of composition and acidity of two extracting mixtures and probably the mechanism of extraction [12]. Both methods extracted the same part of exchangeable and non-exchangeable soil potassium. The higher quantities of ALM extracted potassium could be due not only to the extractant composition, but to the highest soil-to-liquid ratio and longest extraction time. The lower quantity of extracted potassium by Mehlich 1 solution could be explained by the high $\mathrm{pH}$ and CEC of the studied soils, which lower the extraction capacity of Mehlich 1 solution by neutralization.
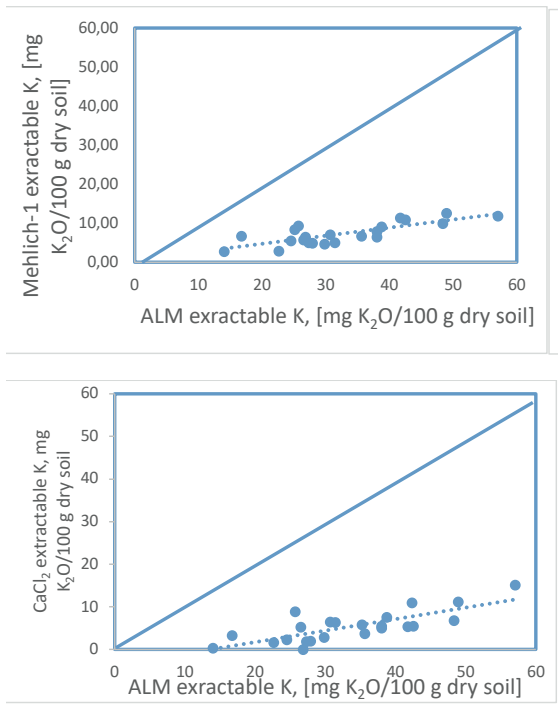

Table 7

Correlation analysis $(\mathrm{P}<0.05 ; \mathrm{df}=22 ; 95 \%$ confidence level)

\begin{tabular}{|c|c|c|c|c|}
\hline & ALM & Mechlih1 & $\mathrm{CaCl}_{2}$ & $\mathrm{NH}_{4} \mathrm{OAc} / \mathrm{HOAC}$ \\
\hline ALM & & & & \\
\hline Mechlih1 & $0.7956^{\mathrm{a}}$ & & & \\
\hline $\mathrm{CaCl}_{2}$ & $0.7688^{\mathrm{a}}$ & $0.7968^{\mathrm{a}}$ & & \\
\hline $\mathrm{NH}_{4} \mathrm{OAC} / \mathrm{HOAC}$ & $0.9494^{\mathrm{a}}$ & $0.6816^{\mathrm{a}}$ & $0.7352^{\mathrm{a}}$ & \\
\hline $\mathrm{BaCl}$ & $0.5662^{\mathrm{a}}$ & $0.5803^{\mathrm{a}}$ & $0.4385^{\mathrm{b}}$ & $0.6629^{\mathrm{a}}$ \\
\hline
\end{tabular}

a - significant $P<0.05, \mathrm{~b}-$ insignificant $P>0.05$.

It was well recognized that the amount of nutrients extracted by a given extraction procedure was not a direct measure of plant availability of nutrients but an index correlated to field calibration [1, 34]. The relationships between K-extracted by different soil testing extractants could provide an information about the parts of extractable potassium and efficiency of given extractant for specific soil types. The correlation coefficients between $\mathrm{K}$ extracted by four studied extracting solutions are shown in Table 7. There was a positive correlation (at 0.05 level of significance) between the quantity of extractable potassium by the studied extraction methods, except between the results from $\mathrm{CaCl}_{2}$ and $\mathrm{BaCl}_{2}$. It should be pointed out that $\mathrm{CaCl}_{2}$ and $\mathrm{BaCl}_{2}$ based extractions differed not only in extracting procedure, but also in detection technique. Although, the results demonstrated that the concentrations of extractable $\mathrm{K}$ varied widely with the method used (Table 5), a significant correlation between the obtained results was observed (Table 7). It could be hypothesized that each extracting procedure desorbed different amount of $\mathrm{K}$, but the similar $\mathrm{K}$ fractions were determined [12]. However, due to the variety of applied extractants and mechanism of extractions comparison of fertility indices based on different test methods could provoke unrealistic estimation of potassium soil status and field calibration needed for Bulgarian arable soils.
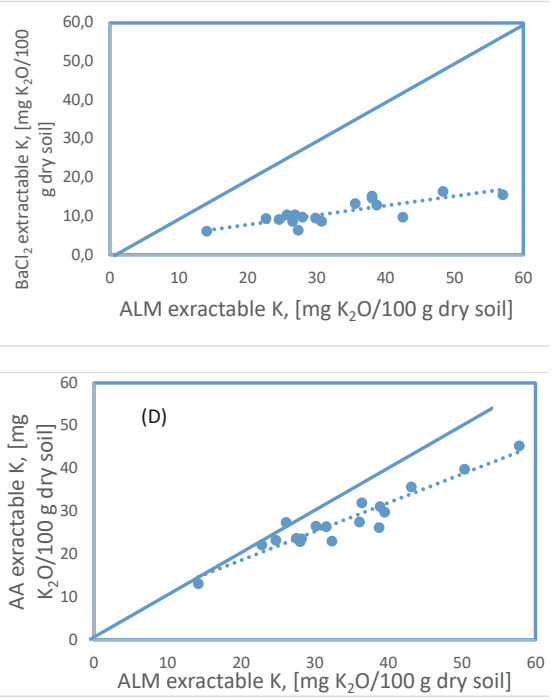

Figure. Comparison of extractability of various soil test methods for $\mathrm{K}$ from soil samples collected at a sample depth of 0 to $30 \mathrm{~cm}$ from agricultural fields in Bulgaria. The dotted line represents the linear regression fit and a solid line - a 1:1 relationship between the tests being compared. 


\section{CONCLUSIONS}

A comparative study on four plant available potassium methods was conducted for Bulgarian arable soils. A modified acetate-lactate method (ALM), Mehlich 1, $\mathrm{NH}_{4} \mathrm{OAc} / \mathrm{HOAc}(\mathrm{AA}), \mathrm{CaCl}_{2}$ and $\mathrm{BaCl}_{2}$ were studied. The results showed that extractable potassium lowered in the following order $K_{\mathrm{ALM}} \geq K_{\mathrm{AA}}>K_{\text {Mechlich } 1}>K_{\mathrm{BaCl}_{2}}>K_{\mathrm{CaCl}_{2}}$. The amount of extractable $\mathrm{K}$ varied widely with the method used with ALM method extracting the highest amount of exchangeable K. A significant correlation between the obtained concentrations of extractable $\mathrm{K}$ by the studied methods was observed, indicating that similar fractions of $\mathrm{K}$ was extracted. The obtained results provided a base for further study on correlation between extractable $\mathrm{K}$ and soil fertility indices for particular soil types and climatic regions in Bulgaria.

\section{ACKNOWLEDGEMENT}

The authors of this study were thankful to prof. Margarita Nikolova for the idea and discussions; to Mr. Vencislav Nekov (Sembodja, Ltd., Sofia, Bulgaria) for providing soil samples. Lyudmila Angelova acknowledged the financial support of the National Program for Support of Young Researchers 2018-2020 funded by the Bulgarian Ministry of Education and Science. The authors are thankful to Ms. Yulia Ivanova for making some of the laboratory experiments.

\section{REFERENCES}

1. Nikolova M., Fixen P., Popp T. Best management practices for sustainable crop nutrition in Bulgaria, BMPSCN Manual on Soil and Plant Analysis and Fertilizer Recommendation. 2014, IPNI-2008-BGR-1, Sofia, Bulgaria (in Bulgarian).

2. Bortolon, L., Gianello, C. Simultaneous multielement extraction with the Mehlich 1 solution for southern Brazilian soils determined by ICP-OES and the effects on the nutrients recommendations to crops. Revista Brasileira de Ciencia do Solo, 2010, vol. 34, pp. 125-132, https://doi.org/10.1590/ S0100-06832010000100013

3. Sikora F.J., Mylavarapu R.S., Hardy D.H., Tucker M.R., Franklin R.E. Conversion equations for soil test extractants: Mehlich 1 and Mehlich 3, 2005, http://soils.rs.uky.edu/m3vsm1. php (last accessed 21 August 2020)

4. Horneck D.A., Sullivan D.M., Owen J.S., Hart J.M. Soil test interpretation guide. Oregon State University, 2011

5. Wang J., Harrell D.L., Henderson R.E., Bell P.F. Comparison of soil-test extractants for phosphorus, potassium, calcium, magnesium, sodium, zinc, copper, manganese, and iron in Louisiana soils. Communications in Soil Science and Plant Analysis, 2004, vol. 35, pp.145-160, DOI: https://doi.org/10.1081/ CSS-120027640.

6. Mylavarapu R.S., Hardy D.H., Tucker M.R., Franklin R.E. Conversion equations for soil test extractants: Mehlich 1 and Mehlich 3. 2005, soils.rs.uky.edu/m3vsm1.php

7. Madaras M., Koubová M. Potassium availability and soil extraction tests in agricultural soils with low exchangeable potassium content. Plant, Soil and Environment, 2015, vol. 61, no. 5 pp. 234-239, DOI: 10.17221/171/2015-PSE 8. Zhang, Y., Nachimuthu G., Mason S., McLaughlin M.J., McNeill A., Bell M.J. Comparison of soil analytical methods for estimating wheat potassium fertilizer requirements in response to contrasting plant $\mathrm{K}$ demand in the glasshouse. Scientific Reports, 2017, vol. 7, no. 11391, DOI: 10.1038/ s41598-017-11681-4.

9. Li X., Zhang Y., Wang W., Khan M.R., Cong R., Lu J. Establishing grading indices of available soil potassium on paddy soils in Hubei province, China. Scientific Reports, 2018, vol. 8, no. 16381, DOI: 10.1038/s41598-018-33802-3

10. Rogers C.W., Dari B., Schroeder K.L. Comparison of soiltest extractants for potassium, calcium, magnesium, sulfur, and micronutrients in Idaho soils. Agrosystems, Geosciences and Environment, 2019, vol. 2, pp. 67, DOI: 10.2134/age2019.08.0067 11. Salomon E. Extraction of soil potassium with $0.01 \mathrm{M}$ calcium chloride compared to official Swedish methods. Communications in Soil Science and Plant Analysis, 1998, vol. 29, no. 19-20, pp. 2841-2854. DOI: 10.1080/00103629809370159

12. Hosseinpur A.R., Samavati M. Evaluation of chemical extractants for the determination of available potassium. Communications in Soil Science and Plant Analysis, 2008, vol.39, no. 9-10, pp. 1559-1570, DOI: 10.1080/00103620802006693 13. Zebec V., Rastija D., Lončarić Z., Bensa A., Popović B., Ivezić $V$. Comparison of chemical extraction methods for determination of soil potassium in different soil types. Eurasian Soil Science, 2017, vol. 50, pp. 1420-1427. DOI: 10.1134/ S1064229317130051.

14. Ivanov P. New acetate-lactate method to determine the available P and K in soil. Soil Science and Agrochemistry, 1984, vol. XIX, pp. 88-98.

15. Pchelarova H., Toncheva R., Parameters of potassium regime for some soils in Bulgaria, Soil science, agrochemistry and ecology, 2013, vol. XL VII (3), pp. 21-25.

16. Uzunov H., Georgiev P., Minev N. Agrochemical analysis of soil from the area of the town Targovishte for determining the value for growing corn. Scientific Works, 2015, LIX, pp: 45-50, DOI: 10.22620/sciworks.2015.05.006

17. Hristov B., Shishkov T., Katchova V., Atanassova E., Atanassova I. Basic chemical and physicochemical characteristics of soils and substrates in the region of Pernik coal mine basin. In: Soil and agrotechnology in a changing world, Sofia, Bulgaria, 2015. 18. Zlatareva E., Nikolov N. Investigation of some chemical parameters of soil fertility / $\mathrm{pH}, \mathrm{P}$ and $\mathrm{K} /$ in creation of artificial pasture, New knowledge journal of science, 2015, pp.152-155 19. Hristov B., Nikova I., Andreeva N. Fertility of soils over loess in the Danubian plain. Bulgarian Journal of Soil Science, 2017, vol.2, pp. 123-132, DOI: 10.5281/zenodo. 2586003

20 . Soil survey standard test method electrical conductivity, Department of Sustainable Natural Resources, https://www. environment.nsw.gov.au/resources/soils/testmethods/ec.pdf (last accessed August 2020).

21. Hendershot W.H., Duquette M. A simple barium chloride method for determining cation exchange capacity and exchangeable cations. Soil Science Society of America Journal, 1986, vol. 50, pp. 605-608, DOI: 10.2136/sssaj1986.03615995005000030013x [2.] Simonis A.D., Setatou H.B. Assessment of available phosphorus and potassium in soils by the calcium chloride extraction method. Communications in Soil Science and Plant Analysis, 1996, vol. 27, pp. 685-694, DOI: 10.1080/00103629609369587 23. P05-001A Jenway Protocol: Determination of available potassium in soils, Bibby Scientific

24. Cuadros-Rodrıguez L., Hernández Torres M.E., López E.A., Egea González F.J., Arrebola Liébanas F.J., Martınez Vidal J.L. Assessment of uncertainty in pesticide multiresidue analytical methods: Main sources and estimation. Analytica Chimica Acta, 2002, vol. 454, pp. 297-314.

25. Magnusson B., Örnemark U. (eds.) Eurachem Guide: The Fitness for Purpose of Analytical Methods - A Laboratory 
Guide to Method Validation and Related Topics, (2nd ed. 2014). ISBN 978-91-87461-59-0. Available from http://www. eurachem.org"

26. Magnusson B., Näykki T., Hovind H., Krysell M., Handbook for Calculation of Measurement Uncertainty in Environmental Laboratories, NORDTEST, 2012

27. Bettencourt Da Silva R., Bulska E., Godlewska-Zylkiewicz B., Hedrich M., Majcen N., Magnusson B. Analytical measurement: Measurement uncertainty and statistics [Joint Research Center, European Commission, 2013, pp. 58-146., DOI: 10.2787/5825 28. International vocabulary of metrology - Basic and general concepts and associated terms (VIM), $3^{\text {rd }}$ Ed., 2012

29. Kruve A., Rebane R., Kipper K., Oldekop M.-L., Evard H., Herodes K., Ravio P, Leito I. Tutorial review on validation of liquid chromatography-mass spectrometry methods: Part I. Analytica Chimica Acta, 2015, vol. 870, pp. 29-4, DOI: 10.1016/j. aca.2015.02.017

30. Kruve A., Rebane R., Kipper K., Oldekop M.-L., Evard H., Herodes K., Ravio P., Leito I. Tutorial review on validation of liquid chromatography-mass spectrometry methods: Part II. Analytica Chimica Acta, 2015, vol. 870, pp. 8-28, DOI: 10.1016/j. aca.2015.02.016
31. Conklin A., Soil Chemistry: Introduction to Soil Chemistry: Analysis and Instrumentation 2nd Edition, Wiley, 2014.

32. Mehlich A. Determination of $\mathrm{P}, \mathrm{Ca}, \mathrm{Mg}, \mathrm{K}, \mathrm{Na}, \mathrm{NH}_{4}$. Short test methods used in soil testing division, Department of Agriculture, Raleigh, 1950, North Carolina, Soil Testing Division Publication No. 1-53

33. Quin P., Liang J., Karamanos R.E., 1991. Comparison of several extractants for available phosphorus and potassium. Soils and crops workshop, University of Saskatchewan, Canada. https://harvest.usask.ca/bitstream/handle/10388/10641/P.\%20 Qian\%20et\%20al.,\%201991.pdf?sequence=1 (last accessed August 2021)

34. Mylavarapu R.S., Sanchez J.F., Nguyen J.H., Bartos J.M. [Evaluation of Mehlich I and Mehlich 3 extraction procedures for plant nutrients in acid mineral soils of Florida]. Communications in Soil Science and Plant Analysis, 2002, vol. 33: pp. 807820., DOI: 10.1081/CSS-120003067

35. Heckman, J.R. Soil Fertility Test Interpretation- Phosphorus, Potassium, Magnesium, and Calcium. Rutgers New Jersey Agricultural Experiment Station Cooperative Extension, 2006. 